\title{
Диагностика тромбоцитопений
}

\author{
А.В. МАЗУРОВ ${ }^{1}$, С.Г. ХАСПЕКОВАำ, С.А. ВАСИАЬЕВ²
}

'Национальный медицинский исследовательский центр кардиологии Минздрава Российской Федерации, Москва, Россия;

${ }^{2}$ Национальный медицинский исследовательский центр гематологии Минздрава Российской Федерации, Москва, Россия

\begin{abstract}
Аннотация

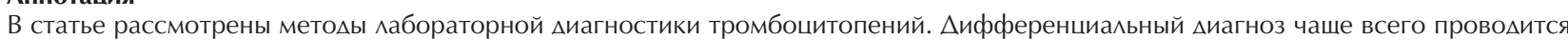
межАу иммунной и гипопродуктивной формами тромбоцитопении. Иммунные тромбоцитопении развиваются вследствие появления в кровотоке антитромбоцитарных антител и ускоренного разрушения сенсибилизированных антителами тромбоцитов, а гипопродуктивные тромбоцитопении - вследствие нарушения продукции тромбоцитов в костном мозге. Главные направления лабораторной диагностики тромбоцитопений связаны с анализом ауто- и аутоантител и оценкой продукции тромбоцитов и их оборота в кровотоке. Аля исследования антитромбоцитарных антител применяют слеуующие методы: 1) измерение количества тромбоцитассоциированных иммуноглобулинов, 2) определение реагируюших с тромбоцитами циркулирующих в плазме антител и 3) опрецеление антител антиген-специфическими методами - по их реакции с изолированными антигенами тромбоцитов. Эффеективность продукции тромбоцитов можно определять по содержанию в крови «молодых» форм тромбоцитов (ретикулярные тромбо-

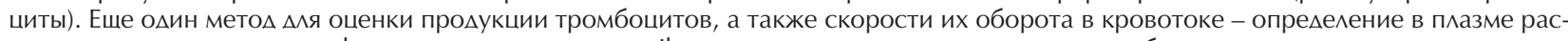
творимого гликокалицина, фрагмента гликопротеина $\mathrm{lb}$, отщеп^яющегося с поверхности тромбоцитов при их разрушении в селезенке и печени. У больных с иммунной тромбоцитопенией всегАа определяются аутоантитела против тромбоцитов, существенно повышено процентное содержание ретикулярных тромбоцитов, а количество плазменного гликокалицина - в пределах нормы или повышено. У больных с гипопродуктивной тромбоцитопенией аутоантитела не выявляются или выявляются на низком уровне, процентное содержание ретикулярных тромбоцитов в пределах нормы или умеренно повышено, а количество плазменного гликокалицина снижено. ОтАельные разделы статьи посвящены диагностике гаптеновых форм иммунных тромбоцитопений (гепарининдуцированная тромбоцитопения и мр.) и амлоиммунных тромбоцитопений (в частности, неонатальной амлоиммунной тромбоцитопении).
\end{abstract}

КАючевые слова: тромбоциты, тромбоцитопении, иммунные тромбоцитопении, антитромбоцитарные антитела, ретикулярные тромбоциты, гликокалицин.

\section{Diagnostics of thrombocytopenias}

\section{A.V. MAZUROV ${ }^{1}$, S.G. KHASPEKOVA' ${ }^{1}$, S.A. VASILIEV ${ }^{2}$}

${ }^{1}$ National Medical Research Center for Cardiology Russian Ministry of Health, Moscow, Russia;

${ }^{2}$ National Medical Research Center for Hematology Russian Ministry of Health, Moscow, Russia

\begin{abstract}
Laboratory methods used for the diagnostics of thrombocytopenias are reviewed. Differential diagnosis is usually carried out between immune and hypoproductive forms of thrombocytopenia. Immune thrombocytopenias are caused by appearance in blood of antiplatelet abtibodies and accelerated destruction of platelets sensibilized by those antibodies, and hypoproductive thrombocytopenias - by impaired platelet production in the bone marrow. Main directions of the laboratory diagnostics of thrombocytopenias - analysis of auto- and alloautoantibodies and evaluation of platelet production and turnover in the blood stream. The following methods are used for the investigation of antiplatelet antibodies: 1) measurement of platelet associated immunoglobulins; 2) determination of circulating antibodies reacting with platelets; 3 ) determination of antibodies using antigen specific methods - by their reactivity with isolated platelet antigens (glycoproteins). Efficacy of platelet production could be assessed by measuring in blood the amount of "young" (reticulated) platelets. One more method for the evaluation of platelet production as well as the rate of platelet turnover - measurement of plasma soluble glycocalicin, glycoprotein $\mathrm{Ib}$ fragment shed from the surface of platelets upon their destruction in spleen and liver. In patients with immune thrombocytopenia autoantibodies are evaluated in all cases, the percentage of reticulated platelets is significantly increased and the amount of plasma glycocalicin is within the normal range or increased. In patients with hypoproductive thrombocytopenia autoantibodies are not detected or detected at low level, the percentage of reticulated platelets is within the normal range or slightly increased and the amount of plasma glycocalicin is lowered. Diagnostics of hapten forms of immune thromocytopenias (heparin-induced thrombocytopenia and others) and of alloimmune thrombocytopenias (neonatal alloimmune thrombocytopenia in particular) are considered in the separate sections of this review.
\end{abstract}

Keywords: platelets, thrombocytopenias, immune thrombocytopenias, antiplatelet antibodies, reticulated platelets, glycocalicin.
АДФ - аденозиндифосфат
ГИТ - гепарин-индуцированная тромбоцитопения
ГП - гликопротеин(ы)
ИТП - иммунная тромброцитопеническая пурпура
ИФА - иммуноферментный анализ
моноАТ - моноклональные антитела
НАИТ - неонатальная аллоиммунная тромбоцитопения
РИА - радиоиммунный анализ
РНК - рибонуклеиновая кислота
TA-IgG - тромбоцит-ассоциированные иммуноглобулины
ТПО - тромбопоэтин

ТФ4 - тромбоцитарный фактор 4

ЭДТА - этилендиаминтетрауксусная кислота

CD - Clusters of Differentiation (Designation), кластеры дифференцировки (обозначения)

HPA - Human Platelet Alloantigens, аллоантигены тромбоцитов человека

HLA - Human Leukocyte Antigens, антигены лейкоцитов человека (антигены комплекса гистосовместимости)

MAIPA - Monoclonal Antibody Immobilized Platelet Antigens тромбоцитарные антигены, иммобилизованные с помощью моноAT 
Нарушения тромбоцитарного звена гемостаза могут быть обусловлены изменением содержания тромбоцитов в крови или нарушениями их функции. Нарушения тромбоцитарного гемостаза, как при количественных, так и при качественных функциональных изменениях тромбоцитов, клинически проявляются в виде геморрагического синдрома микроциркуляторного типа, при котором повышается кровоточивость в первую очередь мелких артериальных сосудов. Появляются синяки, петехии, носовые и десневые кровотечения, меноррагии, возможны кровоизлияния в слизистых оболочках желудочно-кишечного тракта.

В норме количество тромбоцитов в периферической крови составляет 150-450·10\%. Нормальные значения могут несколько различаться в зависимости от пола и возраста обследуемых лиц. Количество тромбоцитов в среднем несколько выше у женщин по сравнению с мужчинами и у детей по сравнению со взрослыми и пожилыми лицами. Существуют и популяционные различия в содержании тромбоцитов. Кроме того, нужно учитывать, что нижние и верхние границы нормальной концентрации тромбоцитов обычно рассчитывают по значениям, соответствующим $2,5 \%$ перцентилям. В связи с этим некоторые отклонения от нормы не обязательно являются признаками патологии, а могут отражать естественную вариабельность этого параметра $[1,2]$.

Тромбоцитопенией формально принято считать снижение содержания тромбоцитов ниже $150 \cdot 10^{9} / л$. Однако, учитывая некоторые различия нормальных значений в разных группах, а также возможные индивидуальные вариации вблизи нижней границы нормы, в реальной клинической практике обследование больных начинают при содержании тромбоцитов ниже $100 \cdot 10 \%$ л. Снижение количества тромбоцитов до $50 \cdot 10 \%$ л клинически обычно никак не проявляется и чаще всего обнаруживается при выполнении анализа крови по тем или иным показаниям. Регистрация геморрагических событий при количестве тромбоцитов выше $50 \cdot 10^{9} / л$ предполагает наличие каких-либо нарушений функциональной активности тромбоцитов, т.е. приобретенной или наследственной тромбоцитопатии. Снижение содержания тромбоцитов ниже $50 \cdot 10^{9} /$ л уже ассоциировано с развитием умеренного геморрагического синдрома, а ниже $20 \cdot 10^{9} /$ л - с возможностью опасных спонтанных кровотечений. Такое критическое снижение количества тромбоцитов требует госпитализации больного и незамедлительного проведения лечебных процедур [3-6].

1. Подсчет тромбоцитов. Для корректного выявления тромбоцитопении необходимо учитывать возможные ошибки при подсчете тромбоцитов в автоматических счетчиках клеток крови, работающих по импедансному принципу (метод Коултера). Во-первых, источником некорректного подсчета тромбоцитов может быть так называемая этилендиаминтетрауксусная кислота (ЭДТА)-зависимая псевдотромбоцитопения, обусловленная наличием в крови некоторых лиц антител против ЭДТА-зависимых антигенов тромбоцитов. Присутствие таких антител приводит к агрегации/агглютинации тромбоцитов при заборе крови в пробирки с ЭДТА в качестве антикоагулянта и ошибочному занижению количества тромбоцитов. Вероятность и величина ошибки возрастает с увеличением временного интервала между забором крови и проведением анализа и в

Сведения об авторах:

Хаспекова Светлана Георгиевна - к.б.н., с.н.с.

Васильев Сергей Александрович - д.м.н., проф., врач-гематолог тех случаях, когда кровь хранится при низкой температуре. Частота встречаемости ЭДТА-зависимой псевдотробоцитопении составляет $0,05-0,1 \%$ [7]. Для исключения такого рода ошибок следует при низком содержании тромбоцитов и отсутствии у обследуемого геморрагического синдрома (особенно если кровь хранилась перед подсчетом более 30-60 мин и тем более при низкой температуре) провести микроскопический анализ тромбоцитов для выявления агглютинатов и/или повторить анализ крови в автоматическом счетчике, но с использованием в качестве антикоагулянта цитрата натрия. Второй причиной ошибок может быть занижение количества тромбоцитов при наследственных патологиях тромбоцитов, ассоциированных с изменением их размера. Увеличение размера характерно для синдрома Бернара-Сулье [дефицит гликопротеина (ГП Ib)], синдрома серых тромбоцитов (дефицит альфа-гранул) и МҮН-зависимых тромбоцитопатий (например, синдром Мея-Хеглина), а уменьшенный размер - для синдрома Вискотта-Олдрича [6]. Все эти патологии сопровождаются снижением количества тромбоцитов, однако их неправильный подсчет (из-за увеличенного или уменьшенного размера) не позволяет провести точную оценку глубины тромбоцитопении. В связи с этим при наличии признаков наследственной тромбоцитопении (геморрагический синдром с детского возраста, зарегистрированное нарушение какойлибо функциональной реакции тромбоцитов и т.д.) целесообразно подсчитать количество тромбоцитов с помощью микроскопии (с оценкой размера тромбоцитов) и/или с помощью проточной цитофлуориметрии. При использовании проточной цитофлуориметрии тромбоциты окрашивают антителами против специфических маркеров, обычно применяя антитела против ГП IIb/IIIa (CD41/CD61) или ГП Ib (CD42b).

2. Классификация тромбоцитопений. В зависимости от механизма развития выделяют несколько патогенетических форм тромбоцитопении (табл. 1) $[4,6,8]$.

Гипопродуктивные тромбоцитопении обусловлены нарушением образования тромбоцитов в костном мозге и обычно являются следствием другого, основного заболевания, при котором происходит угнетение тромбоцитопоэза. Тромбоцитопении, вызванные повышенным разрушением/потреблением тромбоцитов, разделяют на две группы иммунные и не иммунные. Иммунные формы развиваются в результате выработки антитромбоцитарных ауто- или ал-

\section{Таблица 1. КАассификация тромбоцитопений}

1. Гипопродуктивные тромбоцитопении, обусловленные сниженной продукцией тромбоцитов в костном мозге

2. Тромбоцитопении, обусловленные повышенным разрушением или потреблением тромбоцитов

2.1. Иммунные (повышенное разрушение тромбоцитов)

2.2. Не иммунные (повышенное потребление тромбоцитов)

3. Тромбоцитопения распределения (при спленомегалии)

4. Наследственные тромбоцитопении ${ }^{1}$

1Чаще гипопродуктивные. 
лоантител, а не иммунные - вследствие повышенного потребления тромбоцитов при интенсивном внутрисосудистом тромбообразовании. Тромбоцитопения распределения обусловлена секвестрацией тромбоцитов в селезенке при спленомегалии, что приводит к снижению числа циркулирующих в крови тромбоцитов. Наследственные тромбоцитопении встречаются гораздо реже приобретенных и обычно ассоциированы с качественными дефектами тромбоцитов, т.е. с тромбоцитопатиями. Наследственные тромбоцитопении чаще являются следствием нарушения образования мегакариоцитов и/или тромбоцитов в костном мозге и реже - повышенного разрушения тромбоцитов.

В реальной клинической практике дифференциальный диагноз обычно проводят между иммунной и гипопродуктивной формами тромбоцитопении. Во-первых, эти патологии встречаются существенно чаще других, а, во-вторых, остальные виды тромбоцитопений обычно не вызывают сложностей при их диагностике.

3. Диагностика гипопродуктивных тромбоцитопений. Гипопродуктивные тромбоцитопении (другие названия - продуктивные или «центральные» тромбоцитопении, т.е. костномозгового «центрального» генеза) встречаются при различных заболеваниях, которые вызывают подавление мегакариоцитарного ростка костного мозга. К таким заболеваниям относятся: апластическая анемия, разные формы лейкозов (как острых, так и хронических), миелодиспластические синдромы, острая лучевая болезнь, цитостатическая болезнь при химиотерапии и лучевой терапии, метастазы рака в костный мозг и др. Для всех видов гипопродуктивной тромбоцитопении характерно резкое сужение или отсутствие мегакариоцитарного ростка на фоне изменений структуры костного мозга, типичных для той или иной патологии. К числу гипопродуктивных тромбоцитопений можно отнести также редкие формы наследственных тромбоцитопений, при которых нарушения образования тромбоцитов в костном мозге имеют генетически детерминированный характер. Главная причина всех гипопродуктивных тромбоцитопений - подавление образования тромбоцитов. Однако присоединение аутоиммунного компонента, наблюдавшееся у части таких больных (в частности, после неоднократных трансфузий тромбоцитов), может приводить к углублению тромбоцитопении $[4,6,8]$.
Диагностика гипопродуктивной тромбоцитопении требует в первую очередь правильного диагноза первичного заболевания, приводящего к угнетению тромбоцитопоэза, который устанавливают на основании анамнестических данных, анализов крови (наличие анемии, лейкоцитоза и другие характеристики) и, главным образом, характерных изменений в костном мозге, указывающих на подавление мегакариоцитарного ростка. Среди специальных лабораторных тестов, которые применяются для дифференциальной диагностики гипопродуктивных тромбоцитопений, можно выделить методы оценки продукции и оборота тромбоцитов, такие как определение ретикулярных («молодых» форм) тромбоцитов (показатель интенсивности тромбоцитопоэза) и измерение плазменного гликокалицина фрагмент ГП Ib, отщепляющийся при разрушении тромбоцитов (подробное описание методов - см. ниже). При гипопродуктивных тромбоцитопениях количество ретикулярных тромбоцитов снижено (угнетение продукции), но их процентное содержание в популяции не изменено или даже несколько повышено - в первую очередь из-за резкого снижения общего количества тромбоцитов. В то же время у больных с классической формой иммунной тромбоцитопенической пурпуры (ИТП) продукция тромбоцитов и количество ретикулярных тромбоцитов по крайне мере не снижены. В связи с этим при ИТП процентное содержание ретикулярных тромбоцитов в популяции (на фоне снижения общего количества тромбоцитов) резко повышено, как по сравнению с нормой, так и с гипопродуктивной тромбоцитопенией $[9,10]$. Количество гликокалицина в плазме при гипопродуктивных тромбоцитопениях снижено вследствие уменьшения количества появляющихся в крови и соответственно разрушаемых тромбоцитов, т.е. снижения их оборота (табл. 2) [10-14]. Это отличает гипопродуктивную тромбоцитопению от иммунных форм, при которых оборот и количество разрушаемых тромбоцитов не снижаются, и концентрация гликокалицина обычно находится в пределах нормы или повышена. При гипопродуктивных тромбоцитопениях, в отличие от других видов тромбоцитопений и, в частности, тромбоцитопений иммунного генеза, наблюдается существенное повышение в плазме содержания свободного тромбопоэтина (ТПО; см. табл. 2) [10, 13-15]. Это обусловлено тем, что общее количество циркулирующих в

Таблица 2. Количество гликокалицина и ТПО в плазме крови у больных с гипопродуктивной и иммунной тромбоцитопенией (ИТП)

\begin{tabular}{|c|c|c|c|}
\hline Показатель & Здоровые доноры & Гипопродуктивная тромбоцитопения ${ }^{1}$ & ИТП \\
\hline $\begin{array}{l}\text { Количество тромбоцитов, } \\
\cdot 10^{9} / \text { л }\end{array}$ & $200 \pm 10(n=38)$ & $\begin{array}{l}31 \pm 6(n=19) \\
p(\text { (ЗД) }<0,001\end{array}$ & $\begin{array}{l}24 \pm 2(n=107) \\
p(\text { ЗД) }<0,001 \\
p(\text { ГПТ }<0,001\end{array}$ \\
\hline Гликокалицин, \%² & $104 \pm 5(n=38)$ & $\begin{array}{l}28 \pm 2(n=19) \\
p(\text { ЗД) }<0,001\end{array}$ & $\begin{array}{l}120 \pm 7(n=107) \\
p(\text { ЗД) }>0,05 \\
p(\text { ГПТ }<0,001\end{array}$ \\
\hline ТПО, пг/мл & H.o ${ }^{3}$ & $958 \pm 191(n=12)$ & $\begin{array}{l}11 \pm 4(n=53) \\
p(\Gamma \Pi \mathrm{T})<0,001\end{array}$ \\
\hline
\end{tabular}

Примечание. Представлены средние \pm ошибки среднего ( $n$ - количество протестированных доноров или пациентов),

$p$ (ЗД) и $p$ (ГПТ) - достоверности отличий от групп здоровых доноров и больных с гипопродуктивной тромбоцитопенией соответственно.

${ }^{1} 13$ больных с апластической анемией, 4 с хроническим и 2 с острым лейкозом.

${ }^{2}$ Процент от контроля, где $100 \%$ - это уровень гликокалицина в стандартном пуле плазм здоровых доноров.

${ }^{3}$ Н.о. - не определяли.

Данные из публикации авторов [14]. 
крови тромбоцитов резко снижено и поэтому уменьшается содержание связанного с тромбоцитами ТПО и увеличивается содержание его свободной формы.

Следует отметить, что у части больных с гипопродуктивной тромбоцитопенией могут выявляться и антитромбоцитарные антитела, хотя и существенно реже и в меньшем количестве, чем у больных с иммунными тромбоцитопениями. Приблизительно у 40-60\% пациентов регистрируется умеренное повышение тромбоцит-ассоциированных иммуноглобулинов (TA-IgG), а реагирующие с тромбоцитами циркулирующие антитела определяются у 5-10\% больных $[14,16]$ (подробное описание методов - см. ниже). Причины этого явления остаются неясными. Появление антитромбоцитарных аутоантител у больных с гипопродуктивной тромбоцитопенией часто регистрируется после неоднократных переливаний тромбоцитов, проводимых без учета их аллоантигенной совместимости. Почему аллогенная иммунизация приводит к изменению толерантности по отношению к собственным тромбоцитам больного также остается непонятным. В любом случае присоединение иммунного компонента на фоне основного заболевания, вызывавшего угнетение образования тромбоцитов в костном мозге, обычно способствует углублению тромбоцитопении и повышает риск геморрагических осложнений.

4. Диагностика иммунных тромбоцитопений. Тромбоцитопении, в основе патогенеза которых лежит повышенное разрушение или потребление тромбоцитов, принято разделять на иммунные и не иммунные формы. При этом иммунные формы встречаются существенно чаще не иммунных.

При иммунных тромбоцитопениях ускоренное удаление тромбоцитов из кровотока обусловлено выработкой антитромбоцитарных аутоантител. Тромбоциты, содержащие антитела на своей поверхности, быстрее выводятся из крови макрофагальными клетками селезенки и печени, содержащими реагирующие с этими иммуноглобулинами Fc-pe- цепторы. Несмотря на то, что при тромбоцитопениях иммунного генеза основной причиной снижения числа тромбоцитов является их ускоренное разрушение, у части больных может регистрироваться и некоторое угнетение тромбоцитопоэза (обычно при хроническом течении заболевания), которое предположительно обусловлено действием аутоантител на мегакариоциты костного мозга [4-6].

Тромбоцитопении потребления не иммунной природы встречаются гораздо реже и развиваются вследствие участия значительного числа тромбоцитов в тромбообразовании. Снижение содержания тромбоцитов в кровотоке по этому механизму наблюдается при синдроме диссеминированного внутрисосудистого свертывания, тромботической тромбоцитопенической пурпуре и гемолитическом уремическом синдроме, массивных кровотечениях и тромбозах, и редких формах наследственных патологий, связанных с повышенной склонностью тромбоцитов к внутрисосудистой агрегации. Потребление тромбоцитов в результате внутрисосудистых тромбозов может также вносить свой вклад в развитие тромбоцитопении при антифосфолипидном синдроме и редких формах иммунной тромбоцитопении, сопровождающихся активацией тромбоцитов [наиболее известный пример - гепарин-индуцированная тромбоцитопения (ГИТ) II типа] [4, 6, 8].

Тромбоцитопении иммунной природы обычно классифицируют в зависимости от механизма образования и антигенной направленности антитромбоцитарных антител. При аутоиммунных заболеваниях аутоантитела могут вырабатываться против неизмененных (ИТП) или измененных (гаптеновые формы) антигенов тромбоцитов. При аллоиммунных патологиях аллоантитела направлены против аллоантигенов (индивидуальные варианты одного антигена) тромбоцитов, различающихся у плода и матери (неонатальная аллоиммунная тромбоцитопения - НАИТ) или у донора и реципиента (рефрактерность к переливаниям тромбоцитов). Нозологические формы тромбоцитопений

Таблица 3. Иммунные тромбоцитопении и антитромбоцитарные антитела

\begin{tabular}{|c|c|}
\hline Заболевание & Характеристика антитромбоцитарных антител \\
\hline $\begin{array}{l}\text { 1. Иммунная тромбоцитопеническая } \\
\text { пурпура (ИТП)1 }\end{array}$ & $\begin{array}{l}\text { Аутоантитела против неизмененных антигенов тромбоцитов больного } \\
\text { (обычно ГП IIb-IIIa, ГП Ib) }\end{array}$ \\
\hline $\begin{array}{l}\text { 2. Гаптеновые (гетероиммунные) } \\
\text { тромбоцитопении }\end{array}$ & $\begin{array}{l}\text { Аутоантитела против измененных антигенов тромбоцитов или чужеродных } \\
\text { антигенов на поверхности тромбоцитов }\end{array}$ \\
\hline 2.1. Лекарственные тромбоцитопении & $\begin{array}{l}\text { Аутоантитела против комплекса лекарства с антигеном тромбоцитов } \\
\text { (гепарин - ТФ4, хинин/хинидин - ГП Ib, антагонисты ГП IIb-IIIa - ГП IIb-IIIa } \\
\text { и др.) }\end{array}$ \\
\hline $\begin{array}{l}\text { 2.2. Тромбоцитопении, ассоциированные } \\
\text { с вирусной инфекцией }\end{array}$ & $\begin{array}{l}\text { Антитела против вирусных антигенов, фиксированных на поверхности } \\
\text { тромбоцитов (?) или против измененных тромбоцитарных антигенов (?), } \\
\text { иммунные комплексы, фиксированные на тромбоцитах (?) }\end{array}$ \\
\hline 3. Аллоиммунные тромбоцитопении & $\begin{array}{l}\text { Аллоантитела против аллоантигенов (индивидуальные варианты одного } \\
\text { антигена) тромбоцитов плода или донора }\end{array}$ \\
\hline $\begin{array}{l}\text { 3.1. Неонатальная аллоиммунная } \\
\text { тромбоцитопения }\end{array}$ & $\begin{array}{l}\text { Аллоантитела матери против аллоантигенов тромбоцитов плода (и отца), } \\
\text { отсутствующих у матери (обычно тромбоцит-специфические антигены) }\end{array}$ \\
\hline $\begin{array}{l}\text { 3.2. Рефрактерность к переливанию } \\
\text { тромбоцитов }^{3}\end{array}$ & $\begin{array}{l}\text { Аллоантитела реципиента против аллоантигенов тромбоцитов доноров, } \\
\text { отсутствующих у реципиента (тромбоцит-специфические и HLA антигены) }\end{array}$ \\
\hline
\end{tabular}

${ }^{1}$ Другие названия - идиопатическая тромбоцитопеническая пурпура (ранее применяемое, также с сокращением «ИТП»), аутоиммунная тромбоцитопения.

${ }^{2}$ Гаптеновая природа предполагается, но окончательно не доказана.

${ }^{3}$ Аллоиммунное осложнение лечения уже существующей тромбоцитопении - неэффективность к переливанию донорских тромбоцитов. 
Таблица 4. Аабораторные методы исследования антитромбоцитарных антител, продукции и оборота тромбоцитов

\begin{tabular}{|c|c|}
\hline Исследование & Методы \\
\hline \multicolumn{2}{|l|}{ 1. Анализ антитромбоцитарных антител } \\
\hline 1.1. Тромбоцит-ассоциированные иммуноглобулины & Проточная цитофлуориметрия, ИФА, РИА \\
\hline $\begin{array}{l}\text { 1.2. Циркулирующие антитела, реагирующие } \\
\text { с тромбоцитами доноров }\end{array}$ & Проточная цитофлуориметрия, ИФА, РИА \\
\hline $\begin{array}{l}\text { 1.3. Определение антител (тромбоцит-ассоциированных } \\
\text { и циркулирующих) по реакции с индивидуальными } \\
\text { антигенами тромбоцитов }\end{array}$ & $\begin{array}{l}\text { ИФА с использованием моноАТ для иммобилизации } \\
\text { индивидуальных антигенов }\end{array}$ \\
\hline \multicolumn{2}{|l|}{ 2. Анализ продукции и оборота тромбоцитов } \\
\hline 2.1. Время жизни меченых тромбоцитов & ${ }^{51} \mathrm{Cr}-$ или ${ }^{111} \mathrm{In}$-меченные тромбоциты (в исследовательских целях) \\
\hline 2.2. Ретикулярные тромбоциты (молодые формы) & $\begin{array}{l}\text { Проточная цитофлуориметрия (содержание PHK, } \\
\text { флуоресцентный краситель) }\end{array}$ \\
\hline $\begin{array}{l}\text { 2.3. Плазменный гликокалицин (фрагмент ГП Ib, } \\
\text { отщепляемый при разрушении тромбоцитов) }\end{array}$ & ИФА \\
\hline
\end{tabular}

Таблица 5. TA-IgG у больных с ИТП и гипопродуктивной тромбоцитопенией

\begin{tabular}{|c|c|c|c|}
\hline Показатель & Здоровые доноры $(n=38)$ & ИТП ( $n=107)$ & $\begin{array}{l}\text { Гипопродуктивная тромбоцитопения } \\
(n=19)^{1}\end{array}$ \\
\hline $\begin{array}{l}\text { Количество тромбоцитов, } \\
\cdot 10^{9} / л\end{array}$ & $200 \pm 10$ & $\begin{array}{l}24 \pm 2 \\
p(\text { ЗД })<0,001\end{array}$ & $\begin{array}{l}31 \pm 6 \\
p(\text { (ЗД })<0,001 \\
p(\text { ГПТ }<0,001\end{array}$ \\
\hline TA-IgG, $\%^{2}$ & $100 \pm 7$ & $\begin{array}{l}586 \pm 22 \\
p(\text { ЗД) }<0,001\end{array}$ & $\begin{array}{l}200 \pm 12 \\
p(\text { ЗД })<0,05 \\
p(\text { ГПТ })<0,001\end{array}$ \\
\hline
\end{tabular}

Примечание. Представлены средние \pm ошибки среднего ( $n$ - количество протестированных доноров или пациентов); $p$ (ЗД) и $p($ ГПТ) - достоверности отличий от групп здоровых доноров и больных с гипопродуктивной тромбоцитопенией соответственно.

${ }^{1} 13$ больных с апластической анемией, 4 с хроническим и 2 с острым лейкозом.

${ }^{2}$ Процент от контроля, где $100 \%$ - средний уровень TA-IgG у протестированных здоровых доноров. У больных с ИТП наблюдается высоко достоверная обратная корреляция между уровнем TA-IgG и количеством тромбоцитов (коэффициент корреляции $-0,467, p<0,001)$.

Данные из публикации авторов [14].

иммунного генеза и краткая характеристика ауто- и аллоантител, вызывающих их развитие, представлены в табл. 3.

4.1. Диагностика иммунной тромбоцитопенической пурпуры. ИТП ранее называлась идиопатической тромбоцитопенической пурпурой с тем же сокращением «ИТП». Однако в настоящее время в связи с доказанной иммунной природой этой патологии обозначение «идиопатическая» заменено на «иммунная» с сохранением сокращения «ИТП». Более того, в связи с тем, что проявления пурпуры не всегда сопровождают ИТП (в частности, в случае мягких/умеренных вариантов), иногда предлагается использовать более короткое название - «иммунная тромбоцитопения» с тем же сокращением «ИТП». Однако «иммунная тромбоцитопения», на наш взгляд, представляет собой более широкий термин, охватывающим и гаптеновые и аллоиммунные формы тромбоцитопений, и поэтому его применение для обозначения исключительно ИТП не совсем корректно. В некоторых работах можно также встретить для обозначения ИТП и термин «аутоиммунная тромбоцитопения» $[3,5,17]$.
ИТП является наиболее часто встречающейся нозологической формой тромбоцитопений иммунного генеза приблизительно 2-4 случая на 100000 населения в год. Во взрослом возрасте женщины заболевают ИТП приблизительно в 2 раза чаще мужчин, а в детском возрасте частота заболеваемости у мальчиков и девочек одинакова $[5,18]$.

Первичная клинико-лабораторная диагностика ИТП основана, во-первых, на отклонении диагноза других видов тромбоцитопений - гипопродуктивной (в первую очередь), тромбоцитопении потребления, тромбоцитопении при спленомегалии и наследственных форм. Такая диагностика базируется на изучении анамнеза (приобретенный или наследственный характер заболевания), исследовании костного мозга (состояние мегакариоцитарного ростка), отсутствии лимфопролиферации, увеличения размеров селезенки и других критериях. Важнейшим клиническим фактором диагностики ИТП является эффективность иммуносупрессивной терапии. Повышение числа тромбоцитов при лечении больных кортикостероидами, внутривенном введении иммуноглобулинов и при- 
Таблица 6. Частота повышения TA-IgG и выявления циркулируюших антител у больных с ИТП (взрослого и детского возраста) и с гипопродуктивной тромбоцитопенией

\begin{tabular}{lll}
\hline Заболевания & Повышение TA-IgG, $\%$ & $\begin{array}{l}\text { Выявление циркулирующих антитром- } \\
\text { боцитарных антител, } \%\end{array}$ \\
\hline ИТП, взрослые & $95(19 / 20)$ & $55(11 / 20)$ \\
ИТП, дети & $100(25 / 25)$ & $8(2 / 25)$ \\
Гипопродуктивная тромбоцитопения ${ }^{1}$ & $65(22 / 34)$ & $12(8 / 66)$ \\
\hline
\end{tabular}

Примечание. Представлено процентное содержание больных с повышением TA-IgG (более 200\% от уровня здоровых доноров) и выявленными циркулирующими антитромбоцитарными антителами, в скобках указано их абсолютное количество к общему количеству протестированных пациентов.

${ }^{1}$ Больные с лимфопролиферативными заболеваниями и количеством тромбоцитов $<100 \cdot 10^{9} / л$.

Данные из публикаций авторов $[16,25]$.

менении других иммуносупрессоров однозначно указывает на наличие иммунного компонента в развитии тромбоцитопении [5, 6, 17].

Среди специальных лабораторных методов, применяемых для дифференциальной диагностики иммунных (ИТП и др.) и не иммунных видов тромбоцитопений (главным образом гипопродуктивных) можно выделить: 1) методы исследования антитромбоцитарных аутоантител (идентификация, количественное измерение, определения антигенной направленности), 2) методы оценки продукции и оборота тромбоцитов (табл. 4).

4.1.1. Методы исследования антитромбоцитарных антител. Определение антитромбоцитарных антител проводится или на поверхности тромбоцитов пациента (связанные или ассоциированные с тромбоцитами антитела) или в сыворотке/плазме пациента по их реакции с тромбоцитами донора (циркулирующие антитела) [19-23].

Для оценки содержания антител на поверхности тромбоцитов пациента чаще всего проводят измерение общего уровня TA-IgG. Количество TA-IgG определяют по реакции меченых антител против иммуноглобулинов человека с предварительно отмытыми от плазмы тромбоцитами пациента. Чаще всего используют флуоресцентно меченые антитела, связывание которых с тромбоцитами регистрируют с помощью проточной цитофлуориметрии. Однако возможно применение радиоиммунного и иммуноферментного анализа (РИА и ИФА) с использованием антител меченных соответственно радиоактивной меткой или ферментами (пероксидаза или щелочная фосфатаза). TA-IgG считается недостаточно специфическим показателем, так как его повышение (особенно незначительное по сравнению с контрольными уровнями) не всегда указывает на наличие специфических антител, направленных против тромбоцитарных антигенов. Тем не менее этот показатель часто используется в клинической практике, так как, во-первых, отсутствие повышения TA-IgG всегда служит доказательством отсутствия иммунного вклада в развитие тромбоцитопении, а, во-вторых, уровень повышения TA-IgG коррелирует со степенью снижения числа тромбоцитов (большее количество иммуноглобулинов фиксированных на поверхности тромбоцитов ассоциировано с их более быстрым выведением из кровотока). В одном из проведенных нами анализов зарегистрирована хорошо выраженная и обратная корреляция между количеством TA-IgG и содержанием тромбоцитов у больных с ИТП (коэффициент корреляции $-0,467, p<0,001, n=107)$ [14]. Примеры измерения TA-IgG в группах больных с ИТП и гипопродуктивными тромбоцитопениями представлены в табл. 5 и 6. Повыше- ние TA-IgG регистрируется практически у всех больных с ИТП. Как уже указывалось выше, у части больных с гипопродуктивной тромбоцитопенией также может наблюдаться присоединение иммунного компонента и некоторое повышение $\mathrm{TA}-\mathrm{IgG}$, хотя и менее выраженное, чем при ИТП (см. табл. 5) [14, 16]. Повышение TA-IgG в ряде случаев фиксируется и у части больных с умеренными вторичными тромбоцитопениями при антифосфолипидном синдроме, системной красной волчанке, других аутоиммунных и воспалительных патологиях и некоторых инфекционных заболеваниях [24].

Циркулирующие антитромбоцитарные антитела определяют в сыворотке/плазме пациентов по их реакции с тромбоцитами донора. Чаще всего так же, как и для измерения TA-IgG, используют проточную цитофлуориметрию и реже - РИА или ИФА. Во всех вариантах этих тестов тромбоциты донора предварительно инкубируются с сывороткой/плазмой обследуемого пациента, а уже затем (после отмывки сыворотки/плазмы) со вторыми антителами против иммуноглобулинов человека меченых флуоресцентной, радиоизотопной или ферментной меткой (в зависимости от применяемого метода). Необходимо отметить, что циркулирующие антитромбоцитарные антитела, в отличие от TA-IgG, определяются далеко не у всех больных с ИТП, а приблизительно у 40-60\% (см. табл. 6). Это обусловлено тем, что (1) значительная часть появляющихся в кровотоке антител может быть связана с тромбоцитами (в плазме остается мало свободных антител) и (2) при гетероиммунной (гаптеновой) форме иммунной тромбоцитопении аутоантитела не реагируют с донорскими тромбоцитами, которые не содержат измененные и/или чужеродные антигены (см. ниже). У больных ИТП детского возраста циркулирующие антитела встречаются еще реже (см. табл. 6) [25]. Это, по-видимому, объясняется тем, что у детей развитие ИТП часто ассоциировано с вирусной инфекцией, и в этих случаях аутоантитела могут иметь гаптеновый характер (см. ниже) и не реагировать с тромбоцитами здоровых доноров. Циркулирующие антитела выявляются у некоторых больных с гипопродуктивной формой тромбоцитопении (см. табл. 6) [16]. Обычно это наблюдается после проведенных переливаний тромбоцитов.

Большей специфичностью по сравнению с методами определения $\mathrm{TA}-\mathrm{IgG}$ и циркулирующих антител, реагирующих с тромбоцитами доноров, обладают методы определения антитромбоцитарных антител по их реакции с индивидуальными тромбоцитарными антигенами. Эти антигены (в основном главные мембранные ГП тромбоцитов) обычно иммобилизуют из лизата тромбоцитов с помощью специ- 
фических моноклональных антител (моноАТ) и затем аутоантитела, связанные с определенным иммобилизованным антигеном, выявляют по их реакции с меченными вторыми антителами против иммуноглобулинов человека. Чаще всего такие тесты выполняются в варианте ИФА. Сокращенный вариант названия метода - MAIPA (Monoclonal Antibody Immobilized Platelet Antigens, тромбоцитарные антигены, иммобилизованные с помощью моноАТ). При исследовании тромбоцит-ассоциированных антител в качестве исходного материала используют лизаты тромбоцитов больного, а при исследовании циркулирующих антител лизаты тромбоцитов донора, предварительно обработанных сывороткой/плазмой больного. В обоих случаях для «вылавливания» комплекса антиген - аутоантитело лизаты тромбоцитов инкубируют с моноАТ, иммобилизованными на пластике. Обычно проводят исследования аутоантител, направленных против мажорных антигенов тромбоцитов ГП IIb-IIIа и ГП Ib, так как именно эти антигены чаще других являются мишенями аутоантител при ИТП. Существуют и несколько иные вариантыМАIPA - предварительная инкубация тромбоцитов с моноАТ и затем их лизирование, добавление сыворотки/плазмы к уже иммобилизованным антигенам и некоторые другие. При ИТП положительные ответы в таких тестах регистрируются у 60-80\% больных при исследовании тромбоцит-ассоциированных и у 30 $50 \%$ больных при исследовании циркулирующих антител. Регистрация аутоантител с помощью антиген-специфических методов позволяет однозначно диагностировать тромбоцитопению иммунного генеза, т.е. ИТП. В то же время отсутствие положительных ответов не обязательно является причиной отклонения диагноза ИТП, так как антитела могут быть направлены против минорных антигенов, не исследованных в тесте, и/или против измененных и/или чужеродных антигенов на поверхности тромбоцитов [20-23, 26].

4.1.2. Методы оценки продукции и оборота тромбоцитов. Оценка продукции и оборота тромбоцитов также позволяет проводить дифференциальный диагноз между иммунными и гипопродуктивными тромбоцитопениями. Термин «оборот тромбоцитов» («turnover» в англоязычной литературе) употребляют, когда описывают уровень их обмена в кровотоке, т.е. количество тромбоцитов, проходящих через сосудистое русло за определенный промежуток времени [27]. Очевидно, что оборот тромбоцитов зависит как от скорости продукции тромбоцитов в костном мозге, так и от времени циркуляции тромбоцитов в кровотоке, определяемом скоростью их разрушения. Продукция тромбоцитов и их оборот повышены или мало изменены у больных с иммунной тромбоцитопенией и снижены у больных с гипопродуктивной тромбоцитопенией.

Наиболее информативный и прямой метод оценки скорости разрушения тромбоцитов (один из параметров, влияющий на их оборот) - это определение времени жизни вводимых в кровоток радиоактивно меченных (с помощью ${ }^{51} \mathrm{Cr}$ или ${ }^{111} \mathrm{In}$ ) тромбоцитов [27]. Однако по соображениям безопасности (введение больному радиоизотопной метки) этот метод применяется крайне редко и исключительно в исследовательских целях. В стандартной лабораторно-клинической практике для оценки продукции и оборота тромбоцитов используются другие подходы: (1) определение ретикулярных («молодых» форм) тромбоцитов, и (2) определение в плазме крови гликокалицина - внеклеточного фрагмента ГП Ib, отщепляемого с поверхности тромбоцитов при их разрушении макрофагами селезенки и печени.

Ретикулярные, «молодые» формы тромбоцитов содержат большее количество рибонуклеиновой кислоты (РНК) и поэтому их выявляют по окраске специфическими по от- ношению к РНК флуоресцентными красителями (тиазоловый оранжевый и др.) с помощью проточной цитофлуориметрии. Процентное содержание ретикулярных тромбоцитов значительно повышено у больных с ИТП, как по сравнению со здоровыми донорами, так и больными с гипопродуктивными тромбоцитопениями. Это объясняется ускоренной продукцией тромбоцитов, которая наблюдается у многих больных с ИТП, особенно в острый период заболевания (в отличие от больных с гипопродуктивной тромбоцитопенией). Однако у части пациентов с ИТП, главным образом в случае хронического течения заболевания, ретикулярные тромбоциты не обязательно повышены, в связи с тем, что у таких больных может происходить частичное угнетение тромбоцитопоэза - предположительно вследствие действия аутоантител на мегакариоциты костного мозга $[9,10]$.

Гликокалицин, крупный внеклеточный фрагмент ГП Ib, попадает в кровь в результате протеолитического отщепления с поверхности тромбоцитов при их разрушении. Количество гликокалицина в плазме крови (обычно определяемое с помощью ИФА) коррелирует с оборотом тромбоцитов. Как отмечалось выше, оно всегда резко снижено при угнетенной продукции тромбоцитов (вследствие уменьшения количества разрушаемых тромбоцитов), т.е. у больных с гипопродуктивной тромбоцитопенией. У больных с ИТП гликокалицин обычно или несколько повышен (в острый период) или же не изменен по сравнению со здоровыми донорами. Некоторое снижение гликокалицина у больных с диагностированным ИТП (обычно при хроническом течении заболевания) указывает на частичное подавление тромбоцитопоэза (предположительно в результате действия аутоантител на мегакариоциты) [10-14].

Ряд других лабораторных показателей также может косвенно указывать на изменение продукции и/или оборота тромбоцитов. Как уже было указано выше, в отличие от больных с ИТП у пациентов с гипопродуктивной тромбоцитопенией резко повышен уровень ТПО, в то время как у больных с ИТП он обычно существенно не изменен [10, 13-15]. Также в отличие от больных с гипопродуктивными тромбоцитопениями у больных с ИТП часто наблюдается увеличение среднего объема тромбоцитов (т.е. их размера) $[14,28]$. Это связывают с появлением в крови большого количества «молодых», более крупных тромбоцитов вследствие компенсаторного усиления тромбоцитопоэза.

Характерные изменения различных лабораторных показателей, которые позволяют проводить дифференциальную диагностику ИТП и гипопродуктивных тромбоцитопений представлены в табл. 7.

4.2. Особенности диагностики гаптеновых (гетероиммунных) тромбоцитопений. Гаптеновые (или гетероиммунные) тромбоцитопении развиваются вследствие выработки антител против измененных (в результате взаимодействия с молекулой гаптена) собственных антигенов тромбоцитов или против чужеродных антигенов, фиксированных на тромбоцитах. К этой группе принято относить все виды лекарственных тромбоцитопений, в которых лекарство выступает в качестве гаптена, а также тромбоцитопении, ассоциированные с вирусной инфекцией.

4.2.1. Лекарственные тромбоцитопении. Наиболее известный пример лекарственной тромбоцитопении - это ГИТ II типа (ГИТ II), причиной которой является выработка аутоантител против комплекса гепарина с тромбоцитарным фактором 4 (ТФ4). В случае хинин- и/или хинидин-зависимой тромбоцитопении антигеном аутоантител является комплекс хинина или хинидина с ГП Ib. Эти соединения в настоящее время применяют в качестве лекарственных 
Таблица 7. Аабораторные показатели при дифференциальной диагностике ИТП и гипопродуктивных тромбоцитопений

\begin{tabular}{|c|c|c|}
\hline \multirow{2}{*}{ Показатель } & \multicolumn{2}{|r|}{ Изменения } \\
\hline & ИТП & Гипопродуктивная тромбоцитопения \\
\hline Количество тромбоцитов & $<100 \cdot 10^{9} /$ л & $<100 \cdot 10^{9} /$ л \\
\hline Количество мегакариоцитов & Повышено или не изменено & Снижено \\
\hline \multicolumn{3}{|l|}{ Антитромбоцитарные антитела } \\
\hline TA-Ig & Повышены & Отсутствуют / умеренно повышены \\
\hline Сывороточные / плазменные антитела & Выявляются в 40-60\% & Обычно отсутствуют, выявляются редко \\
\hline $\begin{array}{l}\text { Ретикулярные тромбоциты (\% от об- } \\
\text { щего количества тромбоцитов) }\end{array}$ & Резко повышены & В норме или умеренно повышены \\
\hline Плазменный гликокалицин & В норме или повышен & Снижен \\
\hline ТПО & В норме & Резко повышен \\
\hline
\end{tabular}

агентов при ряде заболеваний; они также входят в состав некоторых напитков (тоник, швебс). Еще один вариант развития лекарственной тромбоцитопении - выработка аутоантител против комплекса ГП IIb - IIIa с антагонистами этого рецептора (абциксимаб, эптифибатид, тирофибан) [6, 29].

Обычно диагностика лекарственной тромбоцитопении не требует применения специальных методов. Достаточно установить связь тромбоцитопении с началом применения лекарства и зарегистрировать последующее восстановление числа тромбоцитов, ассоциированное с его отменой. Специальные методы диагностики основаны на идентификации в крови пациента антител, реагирующих с лекарством, фиксированным на поверхности тромбоцитов и/или в комплексе с тромбоцитарным антигеном. Для этих целей применяют те же методы, что и при исследовании обычных антитромбоцитарных антител, однако реакцию проводят в присутствии гаптенового лекарственного соединения. Контрольная проба в этом случае не содержит лекарства. Аутоантитела должны выявляться в пробах, содержащих изучаемое лекарство, и не реагировать с контрольными пробами [29].

4.2.1.1. Гепарин-индуцированная тромбоцитопения. ГИТ является наиболее часто встречающейся лекарственной формой тромбоцитопении. Она развивается после введения нефракционированного гепарина и гораздо реже при использовании низкомолекулярных гепаринов. Различают ГИТ I и II типа. ГИТ I типа имеет не иммунный характер и обусловлена незначительной активацией тромбоцитов гепарином и потенцирующим эффектом гепарина на активацию тромбоцитов такими агонистами, как аденозиндифосфат (АДФ), коллаген и др. Этот вид ГИТ развивается достаточно часто и характеризуется умеренным снижением количества тромбоцитов вскоре (в первые дни) после введения гепарина и быстрым восстановлением после его отмены. ГИТ II типа имеет иммунный характер и развивается вследствие образования гаптеновых антител против комплекса гепарин - ТФ4. Антитела в составе таких комплексов, фиксируясь на поверхности тромбоцитов, взаимодействуют с тромбоцитарным Fc-рецептором и стимулируют их активацию, которая приводит к образованию тромбоцитарных агрегатов и внутрисосудистых тромбов. Включение тромбоцитов в такие тромбы приводит к существенному снижению концентрации циркулирующих тромбоцитов обычно более $50 \%$ от исходного уровня и часто ниже
$50 \cdot 10 \%$ л. Таким образом, клиническим диагностическим критерием ГИТ II типа является глубокая тромбоцитопения, ассоциированная с тромбозами. Еще один клинический признак характерный для ГИТ II типа - это манифестация заболевания через 5-10 дней после начала применения гепарина. ГИТ II типа встречается приблизительно в 1$3 \%$ случаев при длительном использовании нефракционированного гепарина, чаще всего при проведении ортопедических и сердечно-сосудистых операций после длительной гепариновой терапии [30].

Специальные тесты для диагностики ГИТ направлены либо на регистрацию активации тромбоцитов антителами против комплекса гепарин - ТФ4, либо на прямое выявление таких антител иммунологическими методами. Наиболее информативным и воспроизводимым активационным тестом является регистрация секреции из плотных гранул тромбоцитов с использованием ${ }^{14} \mathrm{C}$-меченного серотонина при добавлении к ним сыворотки/плазмы больного в присутствии гепарина. Для регистрации антител против комплекса гепарин - ТФ4 применяют различные коммерческие наборы, базирующиеся как на вариантах классического твердофазового ИФА, так и на детекции антител в жидкой фазе. В качестве мишени используют предобразованный комплекс гепарин - ТФ4 [30].

4.2.2. Тромбоцитопении, ассоциированные с вирусной инфекцией. Тромбоцитопении, ассоциированные с вирусной инфекцией, часто встречаются в детском возрасте. Их развитие может быть инициировано вирусной инфекцией или вакцинацией. У больных взрослого возраста наиболее известны тромбоцитопении, ассоциированные с наличием вируса иммунодефицита человека. И в детском и во взрослом возрасте взаимосвязь тромбоцитопении с вирусной инфекцией регистрируется на основании изучения анамнеза. Во многих случаях содержание тромбоцитов восстанавливается после излечения пациента от вирусного заболевания, однако возможен и переход в хроническую аутоиммунную форму [6, 24].

Для диагностики тромбоцитопений, ассоциированных с вирусной инфекцией, применяют стандартные лабораторные методы. У таких больных регистрируется повышение TA-Ig так же, как и у больных с обычной аутоиммунной тромбоцитопенией. Однако циркулирующие аутоантитела, определяемые по реакции с тромбоцитами здоровых доноров, обычно не выявляются, так как на поверхности донорских тромбоцитов отсутствуют вирусные антигены и/или 
их комплексы с тромбоцитарными белками. Редкое выявление циркулирующих антител характерно для больных ИТП детского возраста (см. табл. 6), что, по-видимому, обусловлено частой вирусной (гаптеновой) этиологией иммунной тромбоцитопении в этой группе.

4.3. Диагностика аллоиммунных тромбоцитопений. Аллоиммунные патологии тромбоцитов развиваются вследствие индивидуальных различий тромбоцитарных антигенов у матери и плода (НАИТ) и донора и реципиента (состояние рефрактерности к переливанию тромбоцитов). При НАИТ аллоантитела вырабатываются матерью против аллоантигенов, присутствующих на поверхности тромбоцитов плода и отца и отсутствующих у матери. При развитии рефрактерности к переливанию тромбоцитов аллоантитела направлены против аллоантигенов, содержащихся на тромбоцитах донора и отсутствующих у реципиента.

4.3.1. Неонатальная аллоиммунная тромбоцитопения. Тромбоцитопения у новорожденного в отсутствие инфекционных и неинфекционных патологий беременности и/или родов, которые могут сопровождаться снижением уровня тромбоцитов, позволяет предполагать присутствие в кровотоке материнских ауто- или аллоантител. Основная дифференциальная диагностика в этих случаях проводится между НАИТ (частота - 1 случай на 1000-2000 новорожденных) и так называемой трансиммунной тромбоцитопенией у новорожденных от матерей с ИТП. При наличии у матери ИТП трансиммунная тромбоцитопения развивается в 20-30\% случаев вследствие перехода материнских аутоантител в кровь плода и новорожденного. В связи с этим важным критерием диагностики НАИТ является исключение диагноза ИТП у матери (нормальный уровень тромбоцитов и отсутствие повышения TA-IgG) [6, 31-33]. Тромбоцитопения у ребенка может иметь и наследственный характер, однако наследственные тромбоцитопении встречаются гораздо реже иммунных и обычно ассоциированы с изменением морфологии и активности тромбоцитов [34].

Специфическая лабораторная диагностика НАИТ направлена в первую очередь на выявление аллоантител в крови матери, реагирующих с тромбоцитами отца и/или ребенка. Такие анализы выполняют стандартными методами для регистрации циркулирующих антитромбоцитарных антител с использованием целых тромбоцитов или иммобилизованных из их лизата тромбоцитарных антигенов. Обычно в качестве мишени используют тромбоциты отца, так как тромбоциты новорожденного труднодоступны в достаточных количествах. Использование антиген-специфических тестов в большинстве случаев позволяет также определить аллоантиген, являющийся причиной иммунного конфликта. Однако чаще для этих целей применяют генетические методы, с помощью которых выявляют возможные конфликтные аллоантигены при анализе носительства аллельных вариантов соответствующих генов у матери, отца и ребенка. Наиболее частой причиной НАИТ в европейских популяциях (до 70-80\%) является несовместимость родителей по аллоантигену HРA-1 (HPA - Human Platelet Alloantigen - аллоантиген тромбоцитов человека) или $\mathrm{Pl}^{\mathrm{A}}$ согласно тривиальной номенклатуре. Этот антиген представлен двумя аллельными формами, НРА-1a и НРА-1b $\left(\mathrm{Pl}^{\mathrm{A} 1}\right.$ и $\mathrm{Pl}^{\mathrm{A} 2}$ соответственно), отличающимися заменой лейцина (Leu; HPA-1a) на пролин (Pro; HPA-1b) в 33-м положении молекулы ГП ІІІа вследствие однонуклеотидной замены 1565 T/С в гене этого белка. Обычно происходит иммунизация матери, гомозиготной по более редкому аллоантигену НРА-1b (гомозиготы по этому антигену в европейских популяциях составляют приблизительно 1-2\%), аллоанти- геном НРА-1а, присутствующим на тромбоцитах отца и плода. Второй по частоте причиной развития НАИТ является несовместимость по НРА-5 аллоантигену (Br в соответствии с тривиальной номенклатурой), локализованному в $\alpha 2$-субъединице $\alpha 2 \beta 1$-интегрина. Аллельные варианты определяются однонуклеотидной заменой 1684G/А в мРНК $\alpha 2$-субъединицы, приводящей к замене глутамина (Glu) (HPA-5a, Bra ) на лизин (Lys) (HPA-5b, Brb) в 505-м положении аминокислотной последовательности белка. Различия по этому аллоантигену являются причиной развития 15$20 \%$ НАИТ в европейских популяциях $[6,31,32]$.

4.3.2. Рефрактерность к переливаниям тромбоцитов. Рефрактерность к переливаниям тромбоцитов представляет собой аллоиммунную патологию, которая сама по себе не относится к иммунным тромбоцитопениям, но является осложнением трансфузионного лечения уже существующей тромбоцитопении (обычно гипопродуктивной). Клинически это состояние проявляется в неэффективности переливаний тромбоцитарной массы - быстрое снижение содержания тромбоцитов после проведенной трансфузии. Рефрактерность обычно развивается после неоднократных переливаний тромбоцитов. Ее развитие может быть обусловлено выработкой антител против антигенов комплекса гистосовместимости (HLA - Human Leukocyte Antigens, антигены лейкоцитов человека), против тромбоцит-специфических аллоантигенов (НРА) и даже против антигенов групп крови (ABO) донорских тромбоцитов. В оптимальном варианте подбор доноров должен осуществляться на основании анализа совместимости по всем вышеперечисленным антигенам. В реальной практике начинают с подбора по легко определяемым антигенам АВО, а затем по возможности по HLA и тромбоцит-специфическим НРА антигенам. Возможен также эмпирический подбор доноров по отсутствию реакции циркулирующих антител реципиента с донорскими тромбоцитами. Такие тесты выполняют стандартными методами по выявлению антитромбоцитарных антител в плазме или сыворотке (см. выше) $[6,22,31]$.

Как указано выше, неоднократные переливания тромбоцитов могут приводить не только к развитию рефрактерности к таким трансфузиям, но и к изменению толерантности реципиента по отношению к собственным тромбоцитам и развитию уже аутоиммунной патологии.

Еще одним осложнением переливаний тромбоцитов является так называемая посттрансфузионная тромбоцитопеническая пурпура. Это редкое (в мире описано несколько сотен случаев), но крайне тяжелое заболевание развивается обычно через неделю после трансфузии тромбоцитов и характеризуется глубокой тромбоцитопенией с кровотечениями, в том числе внутричерепными. В большинстве случаев заболевают люди, у которых отсутствует аллоантиген HРA-1a (т.е. гомозиготы по более редкому НРА-1b аллоантигену), после трансфузии НРА-1а положительных тромбоцитов. Практически во всех описанных случаях посттрасфузионная пурпура развивалась у рожавших женщин или пациентов, которым ранее переливались тромбоциты, т.е. у тех, кто уже однажды был иммунизирован по HРА-1а антигену. Происходит выработка антител против этого антигена, которые по непонятным причинам реагируют не только с донорскими тромбоцитами, но и с тромбоцитами пациента, отрицательными по НРА-1a, т.е. аллоиммунные антитела начинают проявлять себя как аутоиммунные [6, 22, 31].

Работа поддержана грантом РФФИ № 16-04-00816. 


\section{АИTEPATYPA/REFERENCES}

1. Segal JB, Moliterno AR. Platelet counts differ by sex, ethnicity, and age in the United States. Ann Epidemiol. 2006; 16: 123-130.

2. Biino G, Santimone I, Minelli C, Sorice R, Frongia B, Traglia M et al. Age- and sex-related variations in platelet count in Italy: a proposal of reference ranges based on 40987 subjects' data. PLOS ONE. $2013 ; 8$ (1): e54289. doi:10.1371/journal.pone.0054289

3. Rodeghiero F, Stasi R, Gernsheimer T, Michel M, Provan D, Arnold DM et al. Standardization of terminology, definitions and outcome criteria in immune thrombocytopenic purpura of adults and children: report from an international working group. Blood. 2009; 113: 23862393.

4. Veneri D, Franchini M, Randon F, Nichele I, Pizzolo G, Ambrosetti A. Thrombocytopenias: a clinical point of view. Blood Transfus. 2009; 7: 75-85.

5. Psaila B, Bussel JB. Immune thrombocytopenia (ITP). In: Platelets. Third edition. (Michelson AD, ed.). Amsterdam, Boston, Heidelberg et al: Academic Press, Elsevier Inc. 2013: 819-833.

6. Мазуров А.В. Физиология и патология тромбоцитов. М.: Литтерра, 2011: 206-251. [Mazurov AV. Platelet physiology and pathology. M.:Litterra, 2011: 206-251. (In Russ.)].

7. Bizzaro N. Pseudothrombocytopenia. In: Platelets. Third edition. (Michelson AD, ed.). Amsterdam, Boston, Heidelberg et al: Academic Press, Elsevier Inc. 2013: 989-997.

8. Michelson AD. The clinical approach to disorders of platelet number and function. In: Platelets. Third edition. (Michelson AD, ed.). Amsterdam, Boston, Heidelberg et al: Academic Press, Elsevier Inc. 2013: 813-818.

9. Kienast J, Schmitz G. Flow cytometric analysis of thiazole orange uptake by platelets: a diagnostic aid in the evaluation of thrombocytopenic disorders. Blood. 1990; 75: 116-121.

10. Kurata Y, Hayashi S, Kiyoi T, Kosugi S, Kashiwagi H. Hoda S, Tomiyama Y. Diagnostic value of tests for reticulated platelets, plasma glycocalicin, and thrombopoietin for discriminating between hyperdestructive and hypoplastic thrombocytopenia. Am J Clin Pathol. 2001; 115: 656-664.

11. Steinberg MH, Kelton JG, Coller BS. Plasma glycocalicin. An aid in the classification of thrombocytopenic patients. N Engl J Med. 1987; 317: 1037-1042.

12. Beer JH, Buchi L, Steiner B. Glycocalicin: a new assay - the normal plasma levels and its potential usefulness in selected diseases. Blood. 1994; 83: 691-702.

13. Kunishima S, Tahara T, Kato T, Kobayashi S, Saito H, Naoe T. Serum thrombopoietin and plasma glycocalicin concentrations as useful diagnostic markers in thrombocytopenic disorders. Eur J Haematol. 1996; 57: 68-71.

14. Khaspekova SG, Shustova ON, Golubeva NV, Vasiliev SA, Mazurov AV. Relationships of mean platelet volume and plasma thrombopoietin with glycocalicin levels in thrombocytopenic patients. Acta Haematologica. 2015; 133: 295-299.

15. Ichikawa N, Ishida F, Shimodaira S, Tahara T, Kato T, Kitano K. Regulation of serum thrombopietin levels by platelets and megakaryocytes in patients with aplastic anaemia and idiopathic thrombocytopenic purpura. Thromb Haemost. 1996; 76: 156-160.

16. Kuznetsov AI, Ivanov AL, Idelson LI, Mazurov AV. Different mechanisms of thrombocytopenia in patients with lymphoproliferative disorders. Eur J Haematol. 1992; 49: 113-118.

17. Provan D, Stasi R, Newland AC, Blanchette VS, Bolton-Maggs P, James B. Bussel JB et al. International consensus report on the investigation and management of primary immune thrombocytopenia. Blood. 2010; 115: 168-186.

18. Terrell DR, Beebe LA, Vesely SK, Neas BR, Segal JB, and James N. George JN. The incidence of immune thrombocytopenic purpura in children and adults: A critical review of published reports. Am J Hematol. 2010; 85: 174-180.

19. Савченко В.Г. Патогенез и методы диагностики идиопатической тромбоцитопенической пурпуры. Тер. Архив. 1979; 51(9): 122-131. [Savchenko VG. Pathogenesis and the methods of diagnosis of idiopathic thrombopenic purpura. Ter Arkh. 1979; 51 (9): 122-131. (In Russ.)].

20. Kelton JG. The serological investigation of patients with autoimmune thrombocytopenia. Thromb Haemost. 1995; 74: 228-233.

21. McMillan R. Clinical role of antiplatelet antibody assays. Semin Thromb Haemost. 1995; 21: 37-45.

22. Зотиков Е.А., Бабаева А. Г., Головкина Л.Л. Тромбоциты и антитромбоцитарные антитела. Монолит. М., 2003. [Zotikov EA, Babaeva AG, Golovkina LL. Platelets and antiplatelet antibodies. Monolit. Moscow, 2003. (In Russ.)].

23. McMillan R. The role of antiplatelet autoantibody assays in the diagnosis of immune thrombocytopenic purpura. Curr Hematol Rep. 2005; 4: 160-165.

24. Cines DB, Liebman H, Stasi R. Pathobiology of secondary immune thrombocytopenia. Semin Hematol. 2009; 46 (1 Suppl 2): S2-14.

25. Анфимова О.М., Хаспекова С.Г., Масчан А.А., Мазуров А.В. Аутоантитела против тромбоцитов при тромбоцитопениях у детей. Бюлл Эксп Биол Мед. 1995; 120 (12): 636-639. [Anfimova OM, Khaspekova SG, Maschan AA, Mazurov AV. Autoantibodies against platelets in thrombocytopenias in children. Biull Eksp Biol Med. 1995; 120 (12): 636-639. (In Russ.)].

26. Анфимова О.М., Хаспекова С.Г., Власова И.В., Мазуров А.В. Определение антигенов антитромбоцитарных антител у больных с различными формами тромбоцитопении. Бюлл Эксп Биол Мед. 1998; 125 (5): 596-600. [Anfimova OM, Khaspekova SG, Vlasova IV, Mazurov AV. Determination of antigens of anti-thrombocyte antibodies in patients with different forms of thrombocytopenia. Biull Eksp Biol Med. 1998; 125 (5): 596-600. (In Russ.)].

27. Penny J. Ballem PJ, Segal GM, Stratton JR, Gemsheimer T, Adamson JW, Slichter SJ. Mechanisms of thrombocytopenia in chronic autoimmune thrombocytopenic purpura. Evidence of both impaired platelet production and increased platelet clearance. J Clin Invest. 1987; 80: 33-40.

28. Kaito K, Otsubo H, Usui N, Yoshida M, Tanno J, Kurihara E, Matsumoto K, Hirata R, Domitsu K, Kobayashi M. Platelet size deviation width, platelet large cell ration, and mean platelet volume have sufficient sensitivity and specificity in the diagnosis of immune thrombocytopenia. Br J Haematol. 2005; 128: 698-702.

29. Aster RH, Curtis BR, McFarland JG, Bougie DW. Drug-induced immune thrombocytopenia: pathogenesis, diagnosis and management. $J$ Thromb Haemost. 2009; 7: 911-918.

30. Greinacher A, Warkentin TE, Chong BH. Heparin-induced thrombocytopenia. In: Platelets. Third edition. (Michelson AD, ed.). Amsterdam, Boston, Heidelberg et al: Academic Press, Elsevier Inc. 2013: 851-882.

31. Kaplan C, Heyu N, Freedman J. Alloimmune thrombocytopenia. In: Platelets. Third edition. (Michelson AD, ed.). Amsterdam, Boston, Heidelberg et al: Academic Press, Elsevier Inc. 2013: 953-970.

32. Bussel JB, Primiani A. Fetal and neonatal alloimmune thrombocytopenia: progress and ongoing debates. Blood Reviews. 2008; 22: 33-52.

33. Koyama S, Tomimatsu T, Kanagawa T, Kumasawa K, Tsutsui T, Kimura T. Reliable predictors of neonatal immune thrombocytopenia in pregnant women with idiopathic thrombocytopenic purpura. Am J Hematol. 2012; 87: 15-21.

34. Lambert MP, Poncz M. Inherited thrombocytopenias. In: Platelets Third edition. (Michelson AD, ed.). Amsterdam, Boston, Heidelberg et al: Academic Press, Elsevier Inc. 2013: 971-988.

Поступила 15.03.2018 